\title{
Immunomodulatory potential of probiotics oraly delivered with $\beta$ - LG to Balb/C mice
}

\author{
Dagmara Złotkowska*', Ewa Wasilewska, Justyna Chudzik-Kozłowska
}

From Food Allergy and Anaphylaxis Meeting 2014

Dublin, Ireland. 9-11 October 2014

Two commercial probiotics preparations were analysed regarding the possibility to induce different $\mathrm{T}$ cells population. Determining CD4+, CD4+CD8+ and CD8+ expression (Tab.1) one was subjected to further experiments and delivered it together with milk allergen $\beta$-LG to Balb/C mice. 14, 21, 28 and 35d from the beginning of experiments specific serum IgG\&IgA, sIgA and copro-IgA were checked. We found significant decrease of humoral response in group fed with $\beta$-LG with probiotic compared to group with $\beta$-LG only, the same time increase specific copro-IgA by 35 days of experiments was observed (Fig. 1). Flow cytometry analysis of $\mathrm{T}$ cells subsets show significant decreased in percentage of CD8+ population in head and neck lymph nodes (HNLN) and spleen (SPL) when probiotic was delivered. In Peyer's Patches elevated number of $\mathrm{CD} 4+\mathrm{CD} 8+$ and $\mathrm{CD} 8+\mathrm{T}$ cell subsets was observed in the same group. During in vitro studies lymphocytes isolated from group $\beta$-LG+probiotic show significant increased CD8+, CD8 $+\mathrm{CD} 4+$ compare to B-LG group. Results show that probiotics has potential to modulate immune answer to food allergens.

\section{Acknowledgements}

The project was funded by the National Science Centre, decision DEC-2011/ 01/B/NZ9/02727.

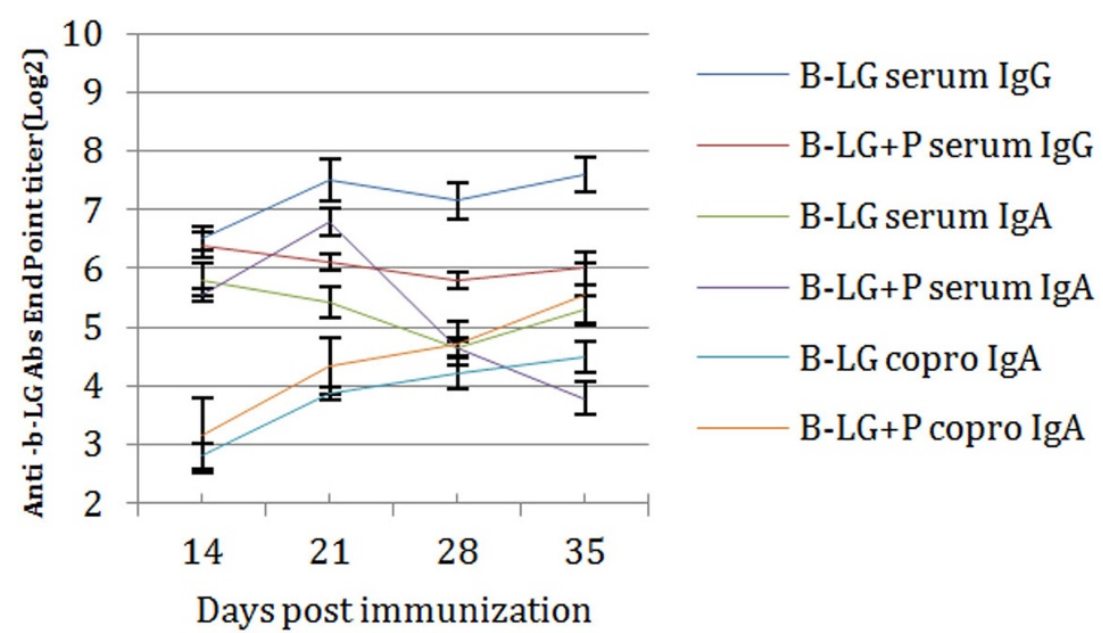

Figure 1 Specific antibodies titer 
Table 1

\begin{tabular}{|c|c|c|c|c|c|}
\hline & & DICOFLOR & SD & PROACTIVE & SD \\
\hline \multirow[t]{3}{*}{ SPL } & CD8 & 9.96 & 0.766 & 9.2 & 1.3 \\
\hline & CD4CD8 & 0.276 & 0.146 & 1.19 & 0.567 \\
\hline & CD4 & 23.9 & 1.62 & 21.7 & 0.808 \\
\hline \multirow[t]{3}{*}{$\mathrm{PP}$} & CD8 & 2.81 & 1.41 & 1.02 & 0.639 \\
\hline & CD4CD8 & 0.26 & 0.149 & 0.609 & 0.914 \\
\hline & CD4 & 12.2 & 4.7 & 3.19 & 0.75 \\
\hline \multirow[t]{3}{*}{ HNLN } & CD8 & 17.6 & 0.952 & 18.1 & 2.12 \\
\hline & CD4CD8 & 1.26 & 0.534 & 0.323 & 0.203 \\
\hline & CD4 & 47.5 & 3.01 & 43.4 & 2.83 \\
\hline \multirow[t]{3}{*}{ MLN } & CD8 & 13.2 & 1.59 & 14.8 & 1.53 \\
\hline & CD4CD8 & 1.1 & 1.14 & 0.842 & 1.04 \\
\hline & CD4 & 45.4 & 14.6 & 52.3 & 4.08 \\
\hline \multirow[t]{3}{*}{ SERUM } & CD8 & 11.7 & 1.01 & 9.18 & 0.479 \\
\hline & CD4CD8 & 0.281 & 0.463 & 0.0554 & 0.0213 \\
\hline & CD4 & 35.6 & 3.42 & 29 & 2.87 \\
\hline
\end{tabular}

Published: 30 March 2015

doi:10.1186/2045-7022-5-S3-P121

Cite this article as: Złotkowska et al:: Immunomodulatory potential of probiotics oraly delivered with $\beta$ - LG to Balb/C mice. Clinical and

Translational Allergy 2015 5(Suppl 3):P121.

Submit your next manuscript to BioMed Central and take full advantage of:

- Convenient online submission

- Thorough peer review

- No space constraints or color figure charges

- Immediate publication on acceptance

- Inclusion in PubMed, CAS, Scopus and Google Scholar

- Research which is freely available for redistribution

Submit your manuscript at www.biomedcentral.com/submit 